\title{
Organizational factors for risk control: Comparison between face-to-face and remote training methods. Analysis of the performance of workers working in the construction of electrical networks.
}

Fatores organizacionais para o controle dos riscos: Comparação entre os métodos de treinamento

presencial e remoto. Análise do desempenho de trabalhadores atuantes na construção de redes

elétricas.

Factores organizativos para el control de riesgos: Comparación entre métodos de formación presencial y a distancia. Análisis del desempeño de los trabajadores que laboran en la construcción de redes eléctricas.

\begin{abstract}
Accidents at work are events that bring losses to the employee, employer and society, both economically and socially. Employee training is an important tool for reducing the number of deviations and, consequently, of occupational accidents and diseases, having a crescent in the remote method during the pandemic. Thus, this paper seeks to demonstrate whether the transition to the remote method of training has changed or altered the way workers act safely in the process of electrical network construction. It also establishes guidelines for the adequate use of digital tools in corporate training, and the professional profile of greater adherence to this type of training. The methodology was divided into four parts, as follows: Literature review; field study, where face-to-face and remote training was conducted; evaluation criteria for the workers who participated in the study; and statistical treatment and data analysis. The workers who did the remote theoretical training had an average of 8.6, while those who did the face-to-face training had an average of 8.0. In the practical training, those who were trained remotely had an average score of 9.0, while those trained in person had an average score of 8.0. The professionals trained through virtual platforms showed similar performance compared to those who received traditional training, when we consider the standard deviations of the statistical analysis. The results indicate that there was no loss in the perception of risk for employees trained virtually, however, the cost of in-person training is 26 times higher than that of remote training.
\end{abstract}

Keywords: Occupational training; Occupational safety; Occupational health and safety management; Construction industry. 


\begin{abstract}
Resumo
Os acidentes de trabalhos são eventos que trazem prejuízos para o empregado, empregador e sociedade, tanto de âmbito econômico, quanto de âmbito social. O treinamento do colaborador é uma importante ferramenta para reduzir o número de desvios e consequentemente de acidente e doenças do trabalho, tendo uma crescent no método remote durante a pandemia. Dessa forma, o trabalho busca demostrar se a transição para o método remoto de treinamentos mudou ou alterou a forma do trabalhador agir com segurança no processo de construção de redes elétricas. Bem como, estabelecer diretrizes para o emprego adequado de ferramentas digitas em treinamentos corporativos, e o perfil profissional de maior adesão para esta modalidade de treinamento. A metodologia foi dividida em 4 partes, sendo elas: Revisão de literatura; estudo de campo, onde foi realizada o treinamento presencial e remoto; critério de avaliação dos trabalhadores que participaram do estudo; e tratamento estatístico e análise dos dados. Os trabalhadores que realizaram o teórico remoto tiveram média de 8,6, enquanto os que realizaram presencial, obtiveram média 8,0. No treinamento prático, quem foi capacitado remotamente teve uma média de 9,0, enquanto os capacitados presencialmente tiveram uma nota média de 8,0. Os profissionais capacitados por meio de plataformas virtuais apresentaram desempenho semelhantes em relação aos que receberam treinamento tradicional, ao considerarmos os desvios padrão da análise estatística. Os resultados apontam que não houve perda na percepção de risco, aos colaboradores treinados virtualmente, contudo o custo do treinamento presencial é 26 vezes maior do que o do treinamento remoto.
\end{abstract}

Palavras-chave: Treinamento ocupacional; Segurança do trabalho; Gestão de segurança e saúde no trabalho; Indústria da construção.

\title{
Resumen
}

Los accidentes de trabajo son eventos que traen perjuicios al trabajador, al empleador ya la sociedad, tanto económica como socialmente. La capacitación de los empleados es una herramienta importante para reducir el número de desviaciones $\mathrm{y}$, en consecuencia, accidentes y enfermedades profesionales, con un aumento en el método remoto durante la pandemia. De esta forma, el trabajo busca demostrar si la transición al método de capacitación a distancia ha cambiado o alterado la forma en que los trabajadores actúan de manera segura en el proceso de construcción de redes eléctricas. Así como establecer pautas para el uso adecuado de las herramientas digitales en la formación empresarial, y el perfil profesional de mayor adherencia a este tipo de formación. La metodología se dividió en 4 partes, a saber: Revisión de la literatura; estudio de campo, donde se realizaron capacitaciones presenciales y a distancia; criterios de evaluación de los trabajadores que participaron en el estudio; y tratamiento estadístico y análisis de datos. Los trabajadores que realizaron la teoría a distancia tuvieron una media de 8,6, mientras que los que realizaron la presencial, obtuvieron una media de 8,0. En la formación práctica, los que se formaron a distancia tuvieron una media de 9,0, mientras que los formados presencialmente tuvieron una nota media de 8,0. Los profesionales formados a través de plataformas virtuales presentaron desempeño similar en relación a los que recibieron formación tradicional, al considerar las desviaciones estándar del análisis estadístico. Los resultados muestran que no hubo pérdida de percepción de riesgo para los empleados formados virtualmente, sin embargo el coste de la formación presencial es 26 veces superior al de la formación a distancia.

Palabras clave: Formación ocupacional; Seguridad del trabajo; Gestión de la seguridad y salud en el trabajo; Industria de construccion.

\section{Introduction}

Accidents at work are events that bring socioeconomic losses to the employee, employer, and society, causing losses that reduce the competitiveness of companies (Barkokébas et al., 2020). However, these accidents can be avoided if there is an understanding of the importance of implementing occupational safety management systems within companies, respecting current laws and seeking other sources for subsidy. According to the Public Ministry of Labor (MPT, 2019), Brazil ranks fourth in the world in occupational accidents. Currently, a work accident happens every 48 seconds and every $3 \mathrm{~h} 38 \mathrm{~min}$ a worker loses his or her life due to the lack of a culture of occupational health and safety prevention (MPT, 2021). Accidents generate direct and indirect costs for employees, employers, and society, which are even higher when the worker dies.

According to occupational accident notifications by economic sector (MPT, 2021), hospital care activities are the most accident prone, currently building construction appears in fifth position with a total of 119,608 accidents. The works for power generation and distribution appear in 18th with 39,312, where it had its peak in 2014, with 6,122 accident notifications. When analyzing accidents in the sector, the top five types of injuries caused were contusion, crushing, fracture, superficial 
Research, Society and Development, v. 11, n. 3, e6011326398, 2022

(CC BY 4.0) | ISSN 2525-3409 | DOI: http://dx.doi.org/10.33448/rsd-v11i3.26398

injury, and cut, respectively. However, when evaluating accidents with fatalities focused on the industry, the highest number of accidents (46\%) was electric shock (MPT, 2021). The top five causative agents in the sector were fall from the same level, transport vehicle, biological agent, motorcycle, and fall from height. However, as with the type of injury caused, if evaluating only with fatalities, electric shock comes first (28\%). Silva (2017) and Costa (2014) consider that mortality rates in emerging countries tend to be higher.

Thus, we observe that electric shock has a high lethality. Although it does not appear among the main causes of accidents in the sector, it is the biggest cause of fatal accidents. A study carried out by Silva and Moreira (2019) points out that these accidents may be associated with insufficient training, inadequate supervision and not knowing the risk. According to the Brazilian Association for Awareness of the Dangers of Electricity (ABRACOPEL, 2021), the lack of risk perception leads professionals and people without technical knowledge of electricity to get involved in accidents. In the year 2020, there were 1502 accidents of electrical origin, 764 fatalities of which 691 were caused by electric shock. The deaths in the electrical sector had as the largest number of victims people with an age range of 31 to 40 years.

The study conducted by Silva (2018), investigated the prevention of the risk of falls at height in building construction, evaluating information provided by the MPT, where he identified that after implementation of administrative and organizational measures provided in Regulatory Standard 35 (NR), among them the training course for working at height, there was a reduction in the number of falls in construction, this being one of the main causes of accidents in the sector. In 2012 (the year of publication of the NR-35 ordinance), work accidents with falls in building construction reached its peak, at 22,111 accidents. When evaluating 3 years after the implementation, the number of accidents reduced to 12,093.

A study conducted by Oliveira et al. (2017), analyzed accidents that occurred between 2012 and 2015 in a company with over 2,000 employees. A 49\% reduction in the number of accidents was identified over the 4 years analyzed. According to the authors, the main actions to reduce the number of accidents were the reductions in the number of deviations, which occurred through training and supervision through indicators and tools (records, checklist, etc.). Trainings are an important tool to reduce the number of deviations and consequently occupational accidents and diseases (American Conference of Governmental Industrial Hygienists [ACGIH], 2020; Aragão et al., 2016; Dalmau et al., 2004; Tachizawa et al., 2003). A study conducted by Almeida Filho et al. (2022) identified that deviations have a direct impact on the performance of occupational safety indicators.

With the scenario currently faced by the world with Covid-19, new technologies have become commonplace for solutions in the workplace and school environment. On March 17, 2020, it was published in the Official Gazette of Pernambuco the suspension of classes in the state because of the pandemic. According to Rocha (2020), a school located in the state started to adopt remote classes through Google tools. The classes using the tool had a daily use of 250 to 400 registered users accessing the Google tool, where it reached $100 \%$ of the students. The study identified access to the platform by several operating systems, such as Android, Windows, Linux, and IOS.

According to Sousa et al. (2022), Google tools were the most used during the pandemic period for Teaching, Santos Junior and Monteiro (2020) consider that there was a significant increase in the use of the Google Classroom tool after the pandemic. The tool is widely used for distance learning and/or active methodologies, using a hybrid teaching. This increase was due to the MEC's Decree announcing the in-person stoppage of PEC (Ministry of Education [MEC], 2020). The author states that the platform became the most chosen for remote mediation, because it does not need to install an exclusive server, besides being online. It is possible to host students and teachers in the room, with easy access and integrated with various Google tools, such as Gmail, Google Drive, Google Docs, Google forms, among others (Google Classroom, 2020). 
Santos Junior and Monteiro (2020) considered Google Classroom an effective tool for distance learning, as well as, Rocha (2020). This tool was used by several other schools and universities in Brazil, for example, the Polytechnic School of the University of Pernambuco, in undergraduate and graduate courses.

A study conducted by Aragão, Pereira-guizzo, \& Figueiredo (2016), performed an analysis of accidents in an industry in the Aratu-BA Pole. It identified 689 accidents over 14 years (2001 to 2015), these accidents had a 32\% reduction after the implementation of expanded training in 2008 (peak of accidents), through the deployment of e-learning platforms. According to Dalmau et al. (2004) define e-learning as a distance learning modality that makes self-learning possible, with the mediation of systematically organized didactic resources, presented in different information technology supports, used isolated or combined, and transmitted through the internet or intranet. According to Tachizawa \& Andrade (2003), this measure enables the expansion in the access to training by the employees, respecting the learning rhythm of the collaborators and reducing costs.

Thus, capacity building and training have an influence on the reduction of accidents, but training workers in the construction sector is challenging, especially when the business has service fronts spread over different regions and far from major urban centers. The activity of electrical network construction is very fragmented, where companies operate in different cities. The company participating in this research operates in the state of Pernambuco in the cities of Recife, Paulista, Cabo de Santo Agostinho, Carpina and Camaragibe, and in the state of Goiás, in the cities of Anápolis, Alexânia, Abadiania, Corumba, Goiânia, Porangatu, Nova Crixás, etc. When evaluating the last 20 years, the company has operated in all the northeastern states. The distance between the work fronts is a factor that hinders the displacement of the instructor to carry out the on-site training.

To combat the accident rate in the sector, the law requires the training of workers. Usually the trainings are in person, but with the advent of Technical Note 54/2018 (Ministry of Labor and Employment [MTE], 2018, occupational safety and health trainings are now authorized through distance learning, semi-attendance, or remote learning, being allowed for all NR trainings (Brazil, 2021). In the following year, Covid- 19 began to be faced in the world, which accelerated the implementation of remote training. A study conducted by Firmino et al. (2022) found that the evaluation of participants of remote learning through platforms was positive.

Energy consumption in Brazil grew by $19 \%$ from 2003 to 2013, while consumption units increased by $28.3 \%$ (National Electric Energy Agency [ANEEL], 2015). To meet this increase, power companies are carrying out grid construction works, which have specific risks. Enel Distribution (2018) described the flow of procedures and risks identified in each phase, according to Table 1.

Table 1 - Flow and risks in the construction of lines and networks.

\begin{tabular}{|c|c|}
\hline Step & Risk \\
\hline Project Interpretation & - \\
\hline Planning and execution of the work & $\begin{array}{c}\text { Hit by a car; Collision; Fall of materials or equipment; } \\
\text { object; Accident with third parties }\end{array}$ \\
\hline $\begin{array}{c}\text { Transportation of equipment and } \\
\text { materials }\end{array}$ & $\begin{array}{c}\text { Vehicle overturn; Inadequate load movement; Impactof project } \\
\text { Personnel Transportation }\end{array}$ \\
\hline
\end{tabular}


Research, Society and Development, v. 11, n. 3, e6011326398, 2022

(CC BY 4.0) | ISSN 2525-3409 | DOI: http://dx.doi.org/10.33448/rsd-v11i3.26398

\begin{tabular}{|c|c|}
\hline $\begin{array}{c}\text { Positioning the Vehicle in the Work Area / Using the } \\
\text { Hoist }\end{array}$ & $\begin{array}{c}\text { Hit by a car; Collision; Fall of materials or equipment; } \\
\text { Vehicle overturn; Inadequate load movement; Impactof projected } \\
\text { object; Accident with third parties }\end{array}$ \\
\hline Work Area Signaling & Hit-and-run. \\
\hline Location & $\begin{array}{l}\text { Stumble; Falling into holes; Animal attacks (bees, } \\
\text { snakes, etc.). }\end{array}$ \\
\hline Trenching & $\begin{array}{c}\text { Accidental Explosion; Rock splintering } \\
\text { Animal attacks (bees, snakes, etc.); Hearingdisturbance. }\end{array}$ \\
\hline Pole Distribution: & Falling poles; Hit by a car; Collision. \\
\hline Pole Deployment & $\begin{array}{l}\text { Accidental fall from poles; Fall of materials or tools; } \\
\text { Electric shock; Electric arc; Collision. }\end{array}$ \\
\hline Assembling Structures & $\begin{array}{l}\text { Accidental fall from poles; Fall from the pole; Fall of } \\
\text { materials or tools; Collision; Misaligned or notproperly fixed to the } \\
\text { ground; Running over. }\end{array}$ \\
\hline Staging & $\begin{array}{l}\text { Accidental falling from poles; Falling materials or tools; Attacks } \\
\text { from aggressive animals, such as bees } \\
\text { and snakes }\end{array}$ \\
\hline $\begin{array}{l}\text { Laying, Leveling, Tensioning and } \\
\text { Connection ofConductors }\end{array}$ & $\begin{array}{l}\text { Falling pole; } \\
\text { Falling materials or tools; Electric shock; Electric arc;Running over; } \\
\text { Attacks from aggressive animals such as bees and snakes. }\end{array}$ \\
\hline Equipment Installation: & $\begin{array}{l}\text { Fall from pole; Fall of materials or tools; Electricshock; Electric arc; } \\
\text { Hit-and-run; Attack by aggressive animals (bees, dogs, etc.); Injuries } \\
\text { caused by sharp materials. }\end{array}$ \\
\hline Grounding & $\begin{array}{l}\text { Fall from the pole; Fall of tools; Hit by a car; Attack } \\
\text { of aggressive animals (bees, dogs, etc.). }\end{array}$ \\
\hline Network overhaul & - \\
\hline Disconnection and reconnection & $\begin{array}{l}\text { Electric Shock; Electric Arc; Running Over; Tool } \\
\text { breakage }\end{array}$ \\
\hline Live Line Interconnection: & $\begin{array}{l}\text { Fall from pole/tools; Shock/electric arc; } \\
\text { Tool/equipment malfunctions. }\end{array}$ \\
\hline Returning the material & $\begin{array}{l}\text { Falling materials; Material damage (damaging } \\
\text { materials and/or equipment). }\end{array}$ \\
\hline
\end{tabular}

Source: Adaptado de Enel Distribuição (2018).

The step described in table 1 is contained within the macro process of the Electric Power System (SEP), where it has the hydroelectric power plants, passing through the generators until it reaches the transmission phase. This stage has the transmission lines and transmission substation, following the transmission line until reaching the distribution substation. In the study, the analysis was applied to the distribution phase, which is branched for residential consumers and commercial and industrial consumers.

According to Mekkodathil et al. (2016) and the International Labor Organization (ILO, 2020), approximately 4\% of the world's Gross Domestic Product (GDP) is lost annually due to occupational accidents and diseases. The costs have links to 
health care, retirements, absenteeism, and rehabilitation, among other factors. The ANEEL (2022) provides information on accidental events unique to the electrical sector. The Figure 1 presents data regarding the number of deaths with accidents at work with own employees (A) and third parties (B) in the period from 2011 to 2020.

Figure 1 - Accidental events in the electric sector.

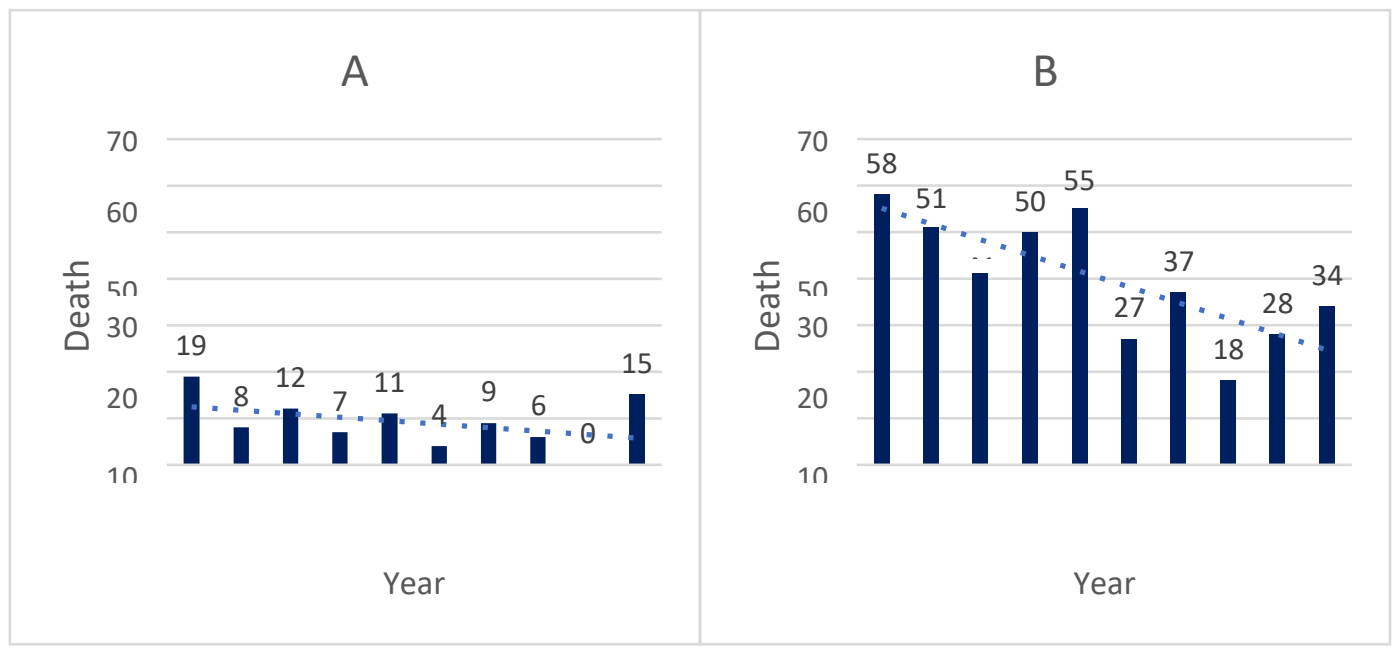

Source: Adapted from ANEEL (2022).

According to the Figure 1 the number of fatal accidents with own employees presented by ANEEL is in a downward trend, but there was a significant increase in 2020, with 15 deaths. The number of accidents with third parties also showed a downward trend, having a higher number of accidents when buying with own employees. The Figure 2 shows the number of accidents involving third parties involving the power grid and its surroundings (other installations), including the number of deaths.

Figure 2 - Accidents with third parties involving the power grid and its surroundings.

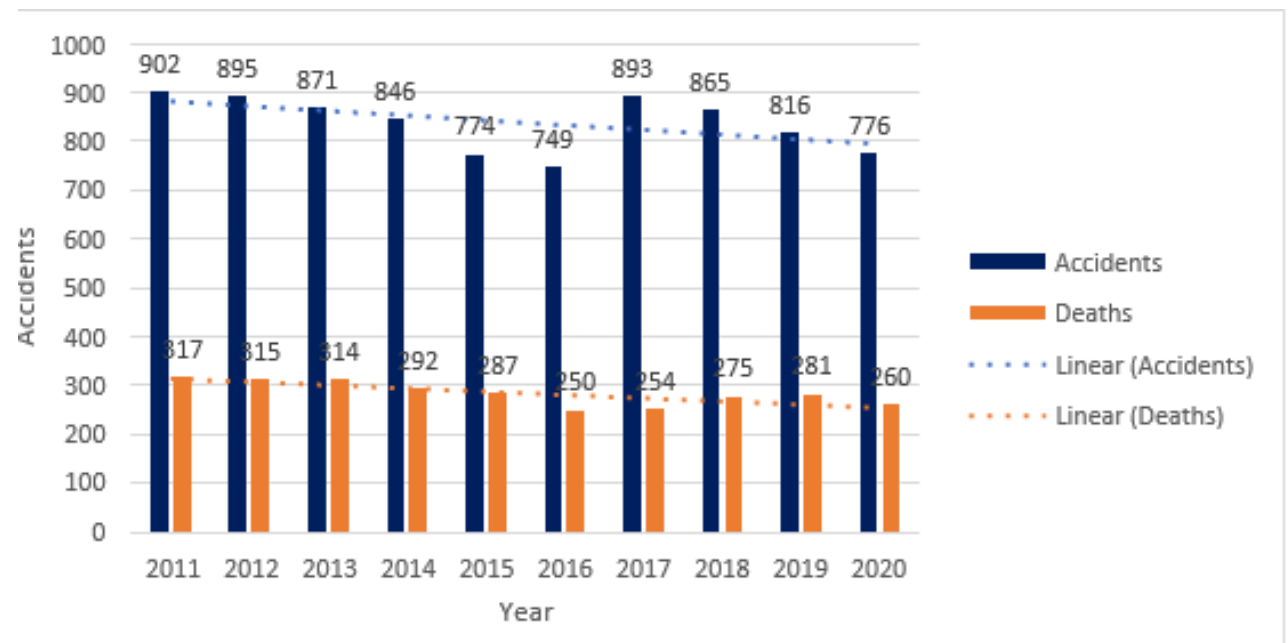

Source: Adapted from ANEEL (2022).

The number of accidents shows a downward trend, although to a lesser extent when compared to the number of deaths. The lowest accident rates were in 2015 and 2016, when there were 774 and 749, respectively. 
Research, Society and Development, v. 11, n. 3, e6011326398, 2022

(CC BY 4.0) | ISSN 2525-3409 | DOI: http://dx.doi.org/10.33448/rsd-v11i3.26398

ANEEL (2022) counted 490 deaths, when considering the number of deaths resulting from accidents at work (own employees and outsourced employees). Considering Dupont's pyramid (Skiba et al., 2005), for the occurrence of 490 deaths, 14,700,000 deviations occurred, corroborating Almeida Filho et al. (2022), which addresses the impacts of deviations in occupational safety. The significant number of deviations shows the need for their treatment, having as one of the tools the workers' training (Aragão et al.,2016) for the control of deviations.

The MTE (2020) points out that electrical power generation and distribution and telecommunications are the occupations with the highest number of accidents involving electric shock (8\%). The occupation with the highest number of accidents within the electrical power distribution group is maintenance electricians.

Considering the lack of knowledge about the risk of workers a causative factor of work accidents in the construction industry, considering that safety training can be conducted remotely, and considering the lack of information about the effectiveness of this type of training on risk perception and conduct of the worker, as well as the profile of greater adherence to this type of training, this study aims to demonstrate whether the transition to the remote method of safety training has changed or altered the way the worker acts safely in the process of construction of electrical networks. As well as establish guidelines for the proper use of digital tools in corporate training, and the professional profile of greater adherence to this type of training.

\section{Methodology}

The development strategy was divided into 4 parts, these being: Literature review; field study; evaluation criteria; Statistical treatment and data analysis. The literature review consisted in searching scientific databases to support the theoretical knowledge of the present study, as well as to direct the practical application. Essa etapa foi fundamental para artigos que apoiam a metodologia utilizada (Aragão et al.,2016; Cruz, 2011; De Assis et al., 2011). The field study was conducted in a company in the electrical network construction sector, where the work environment and its characteristics were determined, the sample was defined, as well as the on-site and remote training technique. In the sequence, the face-to-face and theoretical evaluation criteria were defined, as well as the methodology for the behavior evaluation after the training, and the scoring criteria, among other items. Finally, the method of statistical treatment and data analysis was defined.

The development strategy was divided into 4 parts, these being: Literature review; field study; evaluation criteria; Statistical treatment and data analysis. The literature review consisted in searching scientific databases to support the theoretical knowledge of the present study, as well as to direct the practical application. This step was fundamental for articles that support the methodology used (Aragão et al.,2016; Cruz, 2011; De Assis et al., 2011). The field study was conducted in a company in the electrical network construction sector, where the work environment and its characteristics were determined, the sample was defined, as well as the on-site and remote training technique. In the sequence, the face-to-face and theoretical evaluation criteria were defined, as well as the methodology for the behavior evaluation after the training, and the scoring criteria, among other items. Finally, the method of statistical treatment and data analysis was defined.

\subsection{Literature review}

The bibliographical and documental research served as a basis for continuing the study. It was used to define the method applied (type of research, definition of tools and parameters for risk perception). The literature review searched for indications linked to "accidental events in the construction sector", "risk perception", "training tool", and these searches were conducted in the CAPES, SCOPUS, Web of Science and SAGE databases. The searches were concentrated in the last five years, in Portuguese and English. As well as, reading of the regulatory norms for the selection of training foreseen in the norms 
that apply to the study.

\subsection{Data collection}

The data collection was carried out in an engineering company, which provides electrical network construction services for construction companies in the state of Pernambuco and energy distributors in the Northeast and Midwest. Initially the field study and data collection were conducted with the workers who performed the face-to-face training, then it was applied to the workers who perform remote training. The study was conducted over a 14-month period (June 2020 to August 2021). The data were organized in a Microsoft Excel spreadsheet throughout the research period and processed later.

\subsubsection{Determining the environment and its characteristics}

The activities are carried out at the construction sites of the construction companies, where the workers participating in the study will carry out the construction of the electrical network. In addition to the training offered by the company, the contractor performs the integration of employees, as provided for in NR-18. The team is made up of electricians and assistantand, in some cases, they also have an exclusive employee to drive the vehicle. As for the services provided to energy construction companies, the service is carried out in public places, but the standard operating procedure is uniform across the company. The activity is carried out in outdoor work, and includes work at height and, in some situations, contact with the energized network. Hand tools are used to excavate the soil, with a crane to move the load and implement the pole. The final activity is the laying of cables for the electrical network.

\subsubsection{Sample Definition}

A group of 130 workers was analyzed. The exclusion criterion for the sample was applied to workers who did not take the test and/or theoretical performance analysis and/or on-site performance analysis. Thus, 32 workers who received the theoretical training and 33 workers who received the practical training were used as the sample.

\subsubsection{Training technique}

The worker's training consisted of two modalities (remote and presential) where the same programmatic content was used, with a workload of 64 hours. To perform their activities in the sector of construction of lines and networks, it is necessary that the employee has: Electricity distribution electrician course, minimum 230 hours; NR-10 basic course (40 hours); NR-10 complementary course (SEP) (40 hours), NR-35 working at height course (16 hours). Based on these prerequisites, a course with a workload of 64 hours was offered, referring to the employee's activities according to the operational procedures to be performed, considering the programmed content of the electrician course, NR-10 (basic and complementary), and NR-35.

The contents contained in the training were: Load Movement; Signaling; Access to Risk Areas; Working at Height; Safety in Work with Electricity (NR-10); Technical Instruction of Work Safety; Protection of Machinery and Equipment; PPE/EPC; Driving Operational and Administrative Vehicles; Device for opening keys with load; Grounding of de-energized networks; Operation of disconnecting switches and fuses; Performance and application of APR and Pre APR; Testing of insulated equipment; Use of spurs on double-T and wooden poles; Use of Personal Voltage Detector; Application of APP 5 Golden Rules; Work plan for intervention in MV/LV networks; Work on De-energized Networks in Proximity to the First Level Energized. 


\subsubsection{Face-to-face training}

The on-site training took place in Cabo de Santo Agostinho, a city in the metropolitan region of Pernambuco. The workload applied was 64 hours, and a training room was used, with chairs, use of an image projector, speakers, and a whiteboard. The training was carried out during the Covid-19 pandemic period, protocols had to be adopted. Among the protocols, it was necessary to take temperature measurements at the beginning of each training day, hand out masks, distribute alcohol gel, keep social distance between participants, and keep windows and doors open, among others.

\subsubsection{Conduct analysis protocol}

The remote training was conducted using the Google Classroom tool, together with the Google Meet tool (Google, 2021). The participants were previously added to the platform and instructed on how to access and the training schedule. The content covered was the same as the face-to-face training. The participants were in cities in the states of Goiás, Pernambuco, and Tocantins. The instructor was in Pernambuco. The training methodology varied between synchronous and asynchronous.

\subsection{Evaluation criteria}

After the training, the participants were evaluated to validate the knowledge imparted in the training. The evaluation was divided into two parts, initially a test to validate the theoretical knowledge was applied. If approved, they were considered able to perform a practical activity.

\subsubsection{Face-to-face}

The test to validate the theoretical knowledge applied to the workers who attend the on-site course, was applied at the end of the training, where a questionnaire with 40 questions was created, being them multiple choice, with options from "A" to "D" where there was one correct item per question. To be considered apt, it is necessary to get $60 \%$ of the test right. The test will be corrected manually, and the result published afterwards. There was no maximum time to take the test, and the topics covered were the same as in the training.

\subsubsection{Remote}

The evaluation for the employees who receive online training has the same questions as the printed test, however it was adapted to "Google Forms", a Google forms tool, the same tool applied in a study conducted by Santiago et al (2022). With this tool it is possible to collect and organize information in small or large amounts (Google, 2021). The test is corrected automatically by the system and the employee is informed of the score, pointing out the mistakes made and the correct answer. To be considered apt, the employee needs to get at least $60 \%$ of the test right. If he or she is apt, the employee continues with the process. If unsuitable, they go through a new training course. As with the on-site training, there was no maximum time to complete the test.

\subsubsection{Conduct evaluation after training}

After aptitude in the theoretical training, a conduct evaluation was applied. The objective of the evaluation was to identify deviations committed by workers when executing electrical network construction activities. The evaluation was applied by a reputable educational institution recognized by the MEC or by a qualified professional designated by the company who did not participate in the training. 


\subsubsection{Conduct analysis protocol}

The evaluator requests the examinee, inside a training center, to perform a routine activity of his/her profession, which is defined at the time of the analysis by the evaluator. In this way, the evaluator checks the deviations committed by the team, which has a table with these pre-defined deviations and the score referring to each type of deviation.

\subsubsection{Scoring criteria}

In the evaluation, each employee starts with 100 points. The employee who obtains at least 60 points at the end of the test is considered fit. The Table 2 shows the classification of deviations and their scores.

Table 2 - Evaluation Items.

\begin{tabular}{|c|c|}
\hline ITEM & LOSSES SCORE \\
\hline Golden Rules & 50 \\
\hline Access to Energized Risk Zone & 50 \\
\hline Use of the working at height kit & 50 \\
\hline Non-use or incorrect use of insulating gloves & 50 \\
\hline Non-use or incorrect use of insulating sleeves & 50 \\
\hline Incorrect use of the voltage detector & 50 \\
\hline Ladder tying & 20 \\
\hline Opening and closing keys & 20 \\
\hline Inadequate positioning for the job & 20 \\
\hline Live Line Clamp opening/closing & 20 \\
\hline Use of DAC (Load Break Device) & 20 \\
\hline Material Lifting Set & 20 \\
\hline Rescue kit & 20 \\
\hline Inadequate Supervision & 20 \\
\hline Inadequate Preliminary Risk Analysis & 20 \\
\hline Checklist PPE/EPC/Tools & 20 \\
\hline No voltage test UC & 20 \\
\hline Tidying up and cleaning the workplace & 10 \\
\hline
\end{tabular}

Source: Authors.

The score was divided into 3 intervals, the first of which with the loss of 50 points, considering the employee unfit. 
The criterion to compose this group is given by deviations that can cause a serious or fatal accident. The second group are deviations that can cause work accidents but have the probability of being of lower potential. The third group refers to the organization of the work environment, subtracting 10 points from the employee.

\subsection{Statistical treatment and data analysis}

The data were organized in a Microsoft Excel spreadsheet, where the scores of the employees who took the face-toface evaluation were entered into the spreadsheet. The employees who took the online test had the spreadsheet automatically generated in Google Spreadsheets. In the sequence, all the data were put into a single Microsoft Excel spreadsheet and treated. Initially a descriptive analysis was performed, and then a correlation analysis was performed.

For the training data, graphs were developed that allowed to purchase the online and in-person training. To verify the ratio, median and possible outliers, the boxplot was used in comparison with the training, as per Figure 3.

Figure 3 - Legend for reading the boxplot graphs.

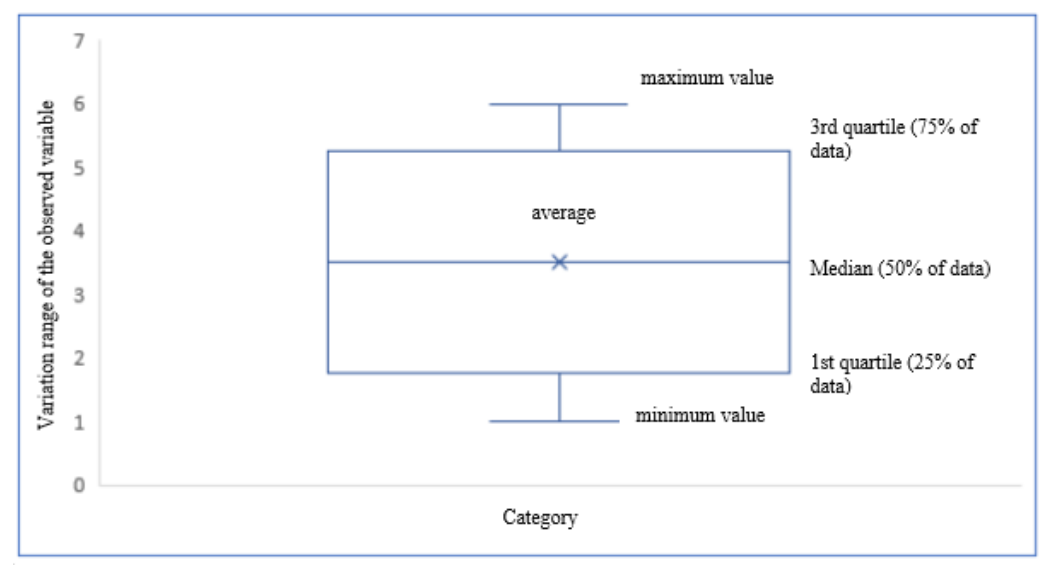

Source: Cruz (2018).

The Figure 3 clarifies how the boxplot is read, where the maximum value represents the largest value observed in the data series, in parallel, the minimum value is the smallest value observed. The median represents the value that divides the data by half. The first quartile represents $25 \%$ of the data, while the third quartile contains $75 \%$ of the data. The mean represents the arithmetic mean of the series (Cruz, 2018).

\section{Results and Discussion}

Based on the literature review performed, the results indicators were defined, which were divided into 6 parts. To better understand the profile of the worker in the electrical network construction sector, an analysis of the workers of the company participating in the research was performed, evaluating their age range, their level of education and their experience. Then, in order to make the remote training feasible, a virtual environment was created using Google Classroom, and after the creation there was a validation of the platform with the remote method. The evaluation of the perception of risks of workers trained face- to-face and remotely was applied after validation, which performed a comparative analysis based on descriptive statistics / correlation. Finally, there was an analysis of the perception of the remotely trained worker and analysis of costs and benefits of the remote and face-to-face method. 
Research, Society and Development, v. 11, n. 3, e6011326398, 2022

(CC BY 4.0) | ISSN 2525-3409 | DOI: http://dx.doi.org/10.33448/rsd-v11i3.26398

\subsection{Profile of the worker studied}

A study conducted by De Assis et al. (2011) with construction workers, including electricians, identified that the age range is a variable to be considered in learning safety training at a distance. Thus, the profile of electrical network construction workers was evaluated in the case studied, in the years 2020 and 2021. Initially, the age distribution of the professionals was evaluated, where $34.2 \%$ of the company's workers are between 31 and 40 years old. The second age group with the highest number of workers is 21 to 30 , which has $32.9 \%$ of the workers, followed by 41 to 50 , with $23.8 \%$, and younger than 20 and older than 60 , both with $0.8 \%$.

The age range of the electrical network construction worker is like the profile identified by De Assis et al (2011) with construction workers, where the authors identified that $80 \%$ of the workers are between 18 and 40 years old.

Another variable that was evaluated by De Assis et al (2011), refers to the level of education of the participants. Thus, it was also an instrument of study, where the educational profile of workers who work with electrical network construction for the case studied. Identifying that $90 \%$ of the workers have completed high school and $2.1 \%$ have a degree. $5.4 \%$ of workers have elementary school I, 2.5\% have middle school. The indicator diverges from the profile outlined by De Assis et al (2011) referring to civil construction, where in their study $7 \%$ have completed high school, and $43 \%$ of participants with early childhood education.

As well as schooling, De Assis et al (2011) evaluated the time employees had been with the company, this being an object of analysis with the workers participating in the research. Where $85 \%$ of the workers of the company, are in the same company for less than 1 year, $10 \%$ have from 1 to 2 years, $2.5 \%$ have from 2 to 5 years in the company, the same percentage of workers with more than 5 years in the company (5\%). De Assis et al (2011) identified that 50\% of employees in his study, have less than 4 years in the company, being a different profile from that identified in this study.

In this way, we can observe that the workers who work in the sector of electrical network construction in the participating company have an average age of 35, with a complete high school education level, and have been in the company for less than 1 year. Considering the profile, it was possible to create a virtual environment for worker training by the remote method.

A study conducted by Netto (2015) compared the traditional method and the use of technology (remote) in the training of workers who work in the security of valuables. In his analysis, the workers who used technology in the training phase (theoretical and practical) had better results when compared to those who trained only by the traditional method.

As observed in the theoretical foundation, training is an efficient method for reducing the number of occupational accidents, as well as the identification and treatment of deviations (ACGIH, 2020; Aragão, Pereira-Guizzo \& Figueiredo, 2016; Dalmau et al., 2004; Oliveira et al., 2017; Tachizawa et al.,2003).

\subsection{Zero Accident Virtual Environment}

As discussed by Rocha (2020), Santos Junior and Monteiro (2020) and Ministry of Education (MEC, 2020), training using the remote method is efficient to pass on the expected knowledge. Thus, the virtual environment named ZERO ACCIDENT VIRTUAL ENVIRONMENT (AVAZ) was developed, which aims to reduce deviations and consequently avoid accidents in the workplace through training, as well as to facilitate the training of workers who perform pulverized activities. For this, the platform allows, for example: The clarification of doubts that may exist by professionals during activities, it is possible to do so in a video call using Google Meet with professionals specialized in the area. It is possible to include a checklist for on-site checking, and to evaluate tools, PPE, EPCs, truck checklist, etc. The activity of electrical network 
construction requires the completion of electrical reports, as required by NR-10, the presence of an acoustic report of the winch and maintenance plan, as required by NR-12, and the presence of work instructions, among others.

AVAZ was developed using the Google Classroom platform, which allows the creation of virtual classrooms for free. Within this environment, it is possible to register employees from partner companies, so that they have access to all content, being a direct tool with workers for communication, dissemination of material, among other mechanisms mentioned. It can also be customized per company.

To access the system, the employee must register/log in at www.google.com, then open the "Google Classroom" platform. At the top of the screen, click on the "+" sign and select the add class option. Finally, enter the code "s3s42f7".

After the creation of the environment, 5 workers participated in a remote training to validate the environment before applying it to the other workers, being them 3 electricians, 1 truck driver and 1 foreman. Due to the SARS-CoV-2 pandemic situation, the training was not conducted in the training room, as it would be a closed environment. The training was held in January 2021.

At the end of the course, an evaluation with 40 questions was applied with the purpose of verifying the class's learning, with the questions having the same weight, being 2.5 points each. The questions were multiple choice, with options from "A" to "D". The same test was applied to all employees. The employees were named as foreman, electrician A, electrician $\mathrm{B}$, electrician $\mathrm{C}$, and driver/maneuverer.

\subsection{Assessment of risk perception of workers trained face-to-face and remotely.}

After validation of the distance method with the 5 research participants, the other employees who were hired in the sequence received the remote training. The simulated applied previously in print was transferred to Google Forms, a complementary tool to Google Classroom of the virtual environment. The 5 participants of the environment validation did not have their scores included in the analysis of the remote training done afterwards. Figure 4 presents the theoretical and practical assessment scores of workers trained using the remote (A) and face-to-face (B) method.

Figure 4 - Practical (A) and Theoretical (B) evaluation.

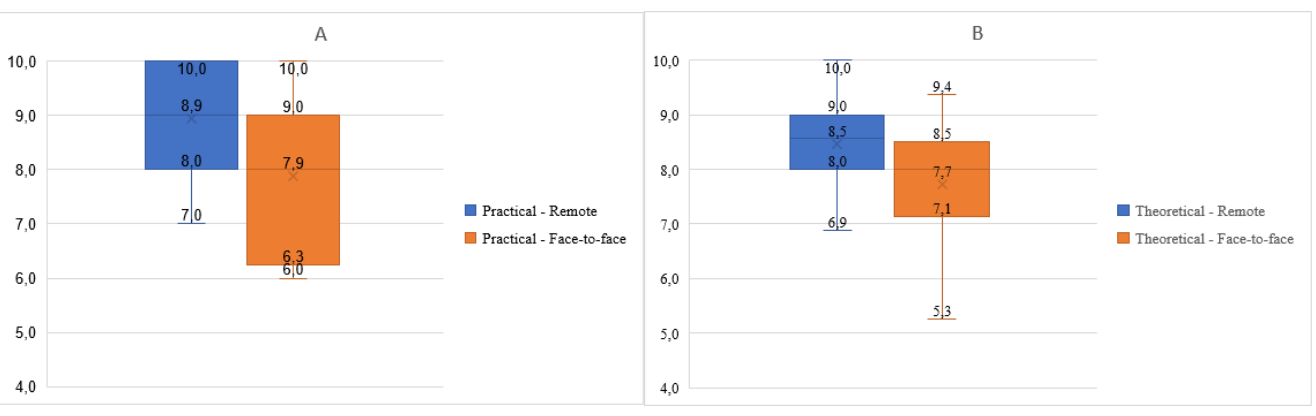

Source: Authors.

The statistical analysis was applied to the practical method, where the workers who took the remote training had a mean practical assessment of 8.9 points, with a standard error of 0.2 and a standard deviation of 0.9. The Median was 9.0, with a minimum of 7.0 and a maximum of 10 . Workers who took the on-site training had a mean of 7.9 points, with a standard error of 0.3 and standard deviation of 1.5, the highest among the items assessed. The median was 8.0, with a minimum of 6.0 and a maximum of 10.0 . 
The workers who received the remote training averaged 1.0 points higher than the workers who were trained in person. The confidence interval of the remote group was 0.7 , while the in-person one was 1.2 . Thus, as in the theoretical evaluation, both methods presented group averages above the minimum considered (6.0). No worker scored below 6.0 .

Workers who took the remote theorical training had a mean of 8.5 points, with a standard error of 0.1 and a standard deviation of 0.8 . The Median was 8.6, with a minimum of 6.9 and a maximum of 10 . Workers who took the in-person training had a mean of 7.7 points, with a standard error of 0.2 and a standard deviation of 1.0. The Median was 8.0, with a minimum of 5.3 and a maximum of 9.4. The average of the remote training was 0.7 points higher than the face-to-face training. It is worth noting that the confidence interval of the remote was 0.7 , while the face-to-face was 0.8 . Thus, both methods have a short variation, and can be said to be similar. In both methods, the average score of the remote and on-site groups were above the minimum average to be considered apt (6.0). Only in the face-to-face method was there a worker with a score below 6.0.

The average of the theoretical and practical using the remote methodology was higher than the face-to-face training, but when considering the standard deviation, we observe the similarity between the scores.

It was analyzed if the score obtained in the theoretical evaluation has interference with the score obtained in the practical evaluation. For this analysis, the correlation method was used, which is the relationship between two variables (Cruz, 2018). Pearson's coefficient (r) was verified, which ranges from -1 to 1 . The sign (negative or positive) means whether it has positive or negative direction between the variables (increases or decreases), as for the value brings the strength of the relationship between the variables. If the value is equal to -1 or 1 (Figure 5), it means a perfect correlation, where we can state that the variable can be determined exactly by knowing the score of the other. On the other hand, a correlation equal to zero indicates that there is no linear relationship between the variables (Filho et al.,2007).

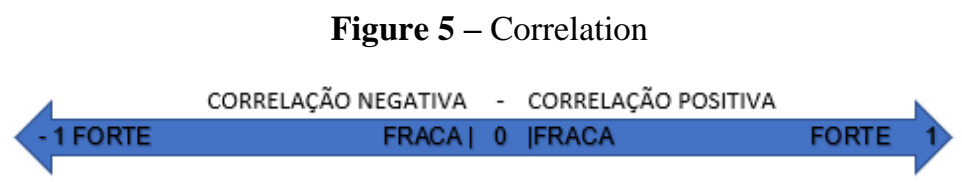

Source: Adapted from Filho \& Silva junior (2007).

To analyze the graph, the classification of Dancey and Reidy (2005) was considered, which considers that: $r=0.10$ to 0.30 there is a weak correlation; for $r=0.40$ to 0.60 there is a moderate correlation; if $r=0.70$ to 1 , it is considered strong. The graph in Figure 6 illustrates correlation evaluation of the variables theoretical evaluation and practical evaluation of the remote (A) and face-to-face (B) method. 
Figure 6 - Practical $x$ theoretical grade: remote (A) and face-to-face (B).

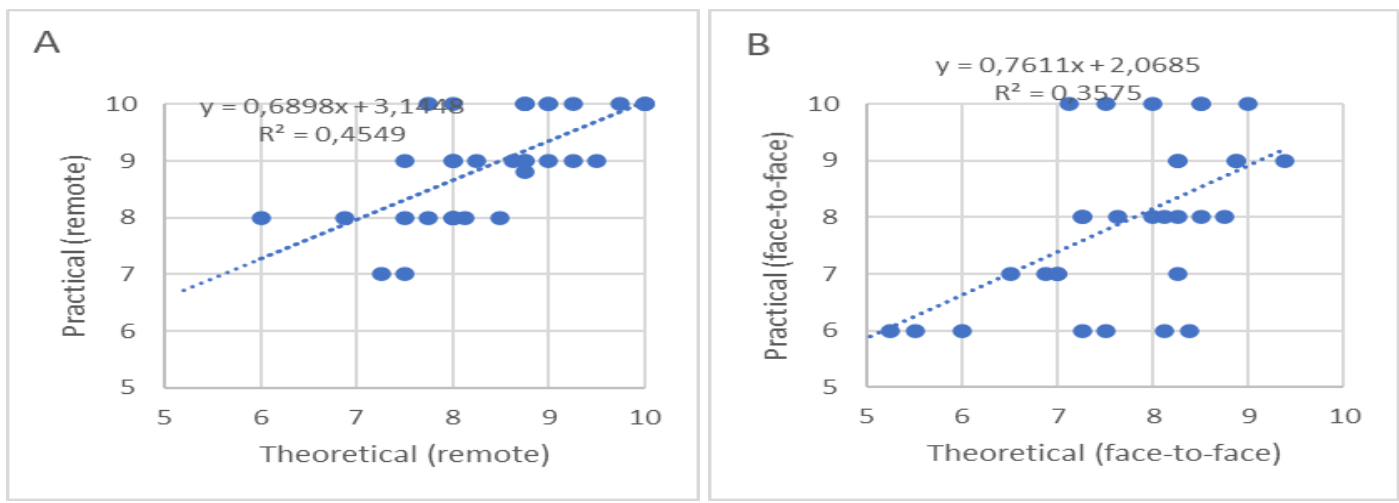

Source: Authors.

As illustrated, $45.5 \%$ of the variation in the practical grade is explained by variation in the theoretical grade of the worker who took the remote training. With $\mathrm{R}=0.7$, being considered a strong correlation, being positive, where the variables move together. Thus, the grade taken in the theoretical evaluation is related to the practical grade. When evaluating the face-toface method, we observe that $35.8 \%$ of the variation in the practical grade is explained by the variation in the theoretical grade of the worker who took the face-to-face training. With $\mathrm{R}=0.6$, being considered a moderate correlation, being positive, where the variables move together.

In both methods, the theoretical score correlates with the practical score, so the worker who has a higher score on the theoretical assessment tends to have a good practical assessment, and the correlation is stronger in remote training.

The age of the participants is a variable to be considered, since the technology can become a difficulty for people with older ages (Silveira et al., 2011), being this a variable considered by De Assis et al. (2011) in a study applied to civil construction and by Caetano et al. (2015) in a study applied to remote teaching for undergraduates. The average age in the case studied of the workers was 33 years old, the age range was 19 to 54 years old, with the largest amount of workers with an age range of 27 to 39 years old. The standard error was 2, with standard deviations of 9 . The workers who participated in the faceto-face training are on average 38 years old, 5 years older than the remote training participants, ranging in age from 23 to 61 years old. Most of the workers are between 28 and 49 years old. The standard error was 2, with standard deviations of 11, the range was 38. Evaluating the age of the workers of both methods, when considering the standard deviation, the ages are equivalent. The scatter plot in the Figure 7 considers the analysis of the variables: practical assessment and age, of the remote method (A) and face-to-face method (B). 
Figure 7 - Practical grade $x$ age: Remote (A) and face-to-face (B).
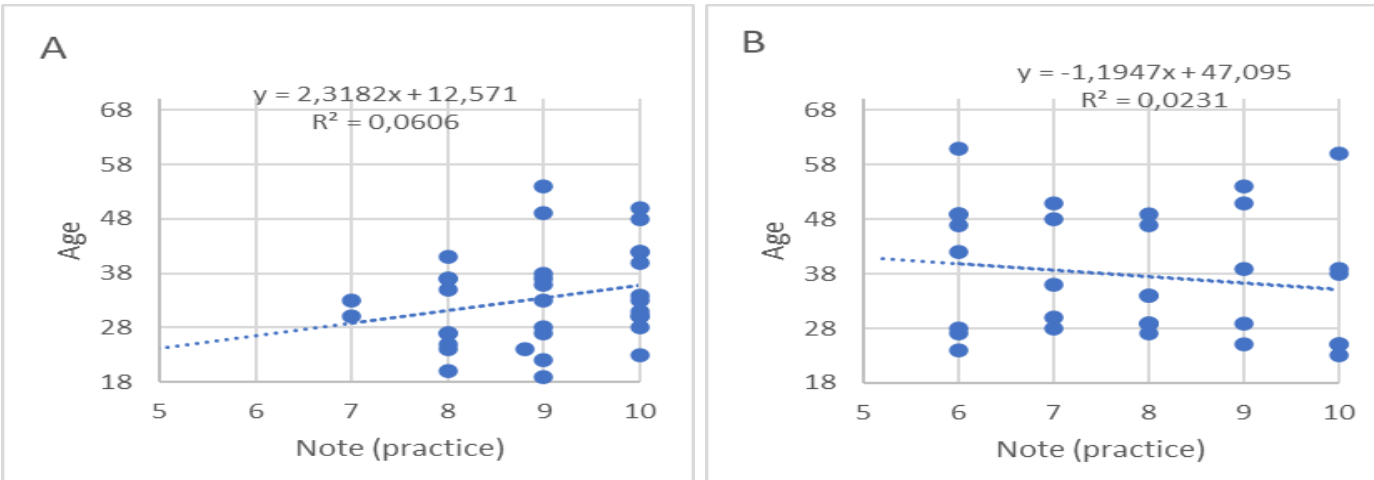

Source: Authors.

The Figure 7 shows that $6.1 \%$ of the variation in the grade is explained by variation in the age of the worker who received remote training. With $\mathrm{R}=0.2$, being considered a weak correlation, being it positive, where they move together. When we consider the same indicators (Practical grade $\mathrm{x}$ age) using face-to-face method, we identify that $2.3 \%$ of the variation in the practical grade is explained by variation in age. With $\mathrm{R}=-0.2$, being considered a weak correlation, being it negative, where the variables move in opposite direction.

We observed that both correlations were considered weak. The age of the worker is not a factor that causes a significant difference in their practical grade, using both methods, diverging from the study conducted by Silveira et al (2011), which identified that age interfered with learning. The figure 8 presents a similar analysis but considering the remote theoretical grade (A) and face-to-face (B).

Figure 8 - Theoretical score $x$ age: Remote (A) and face-to-face (B).

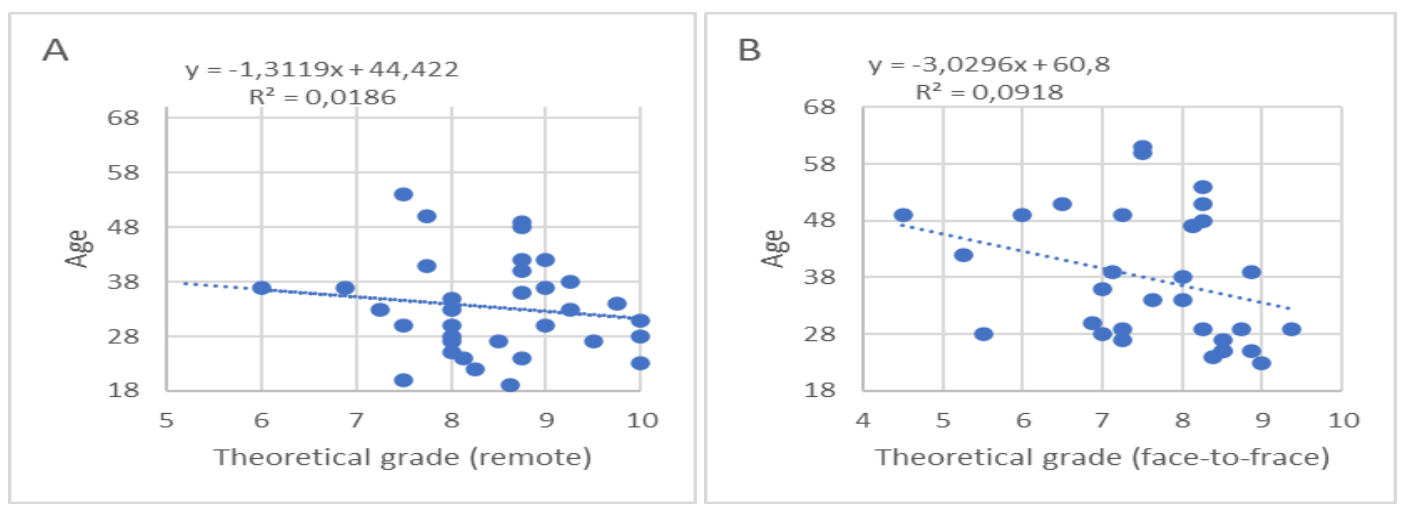

Source: Authors.

The Figure 8 shows that $1.9 \%$ of the variation in the theory score (remote), is explained by variation in the worker's age. With $\mathrm{R}=-0.1$, being considered a weak correlation, being negative, where the variables move in the opposite direction. When evaluating the face-to-face method, we observe that $9.2 \%$ of the variation in the grade is explained by variation in the age of the worker who took the face-to-face training. With $\mathrm{R}=-0.3$, being considered a weak correlation, being negative, where the variables move in the opposite direction.

Thus, we observed that the theoretical score of the training using the remote and on-site methods has a weak 
correlation with the age of the worker. The impact is greater with the on-site training, but still considered a weak correlation.

When analyzing the workers' schooling, a variation from elementary school to high school was obtained. The Table 3 represents the legend that was considered for the construction of the scatter plot.

Table 3 - Schooling.

\begin{tabular}{|c|c|c|c|}
\hline Ord. & Education & Quantity & Method \\
\hline 1 & Illiterate & 0 & - \\
\hline 2 & Elementary I & 4 & Presential - 4 \\
\hline 3 & Fundamental II & 2 & Presential - 1 \\
Remote - 1 \\
\hline 4
\end{tabular}

Source: Authors.

The graph shown in Table 3, represents the evaluation considering the arithmetic mean of the theoretical and practical evaluation, making a correlation with the schooling of the remote (A) face-to-face training (B).

Figure 9 - Average grade x schooling: Remote (A) and On-site (B).

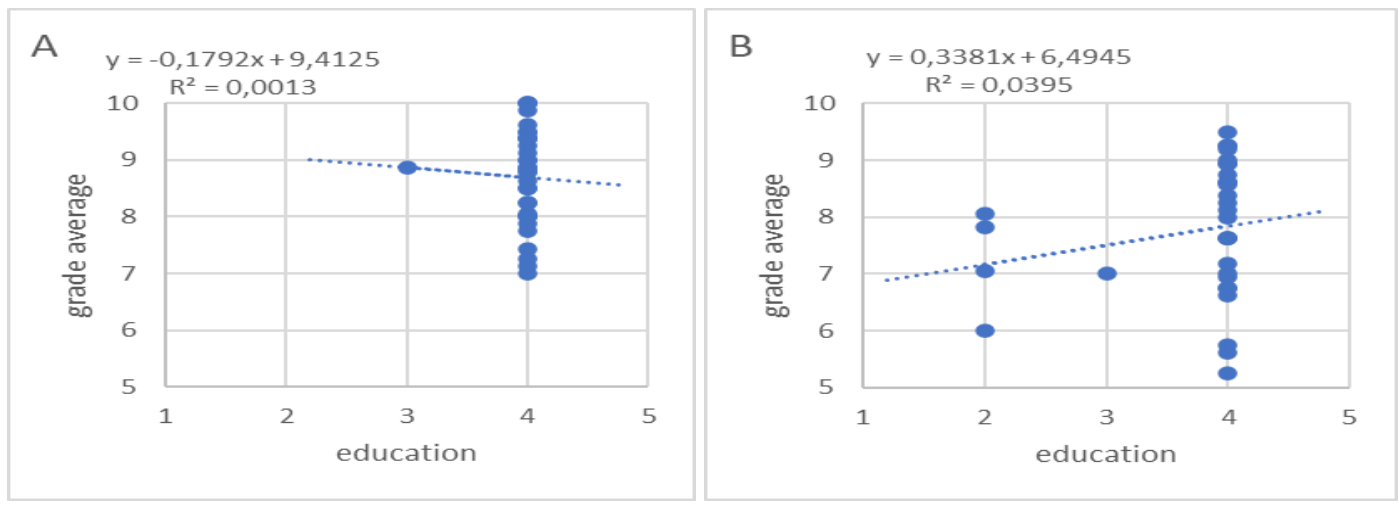

Source: Authors.

In Figure 9, we observe that $4 \%$ of the variation in the score is explained by the variation in the education of the worker who was trained by the on-site method. With $\mathrm{R}=0.2$, being considered a weak correlation, being positive, where the variables move together. The workers who participated in the remote method, only 1 has completed elementary school, the others have completed high school. With $\mathrm{R}=0$, it was identified that there is no linear relationship between the variables when analyzing the schooling with the employees who took the remote training.

Most of the on-site training sample has completed high school, with only 5 workers with different schooling levels, four with elementary school (up to 5th grade) and one with Middle School (up to 9th grade). The lowest average score was obtained by the worker who is in the lowest schooling group of the sample.

\subsection{Cost and benefit analysis of the remote and face-to-face method}

A study conducted by Barros et al (2022), which considered participants with a mean age of 44 years, with a 
predominant level of education, and a mean time of 19 years of experience in their area of work, identified that they had no difficulties in adapting to the use of virtual tools.

While a study conducted by De Assis et al (2011) identified that construction workers, did not score well when being trained remotely. The author associates an influence of low schooling to performance. However, when evaluating the profile of the electrical network construction worker, where $90.90 \%$ of the research participants have completed high school, a good result was obtained, corroborating the influence on schooling cited by De Assis et al (2011).

Workers who were trained remotely had higher mean scores than workers who were trained using the face-to-face method. Most of the remote training scores were higher than 8.0. In all four evaluations applied, scores above the minimum average were observed. Only one worker had a lower score (5.3). The in-person practical training had a greater variation in most of the grades when compared to the other methods. Considering the variation, the averages are equivalent. Concluding that there is no significant difference between methods, diverging from the statistical analysis of the study applied by Caetano et al (2015) for the higher education course, in which classroom training showed better performance.

A study conducted by Netto (2015) considered that the distance from the operational base, the number of participants, and the high cost of transportation, food, and overtime are difficulties in conducting training. Among the benefits brought by distance training, Carvalho and Freitas (2013) mention:

Table 4 - Benefits of distance learning.

\begin{tabular}{|c|c|}
\hline Costs & 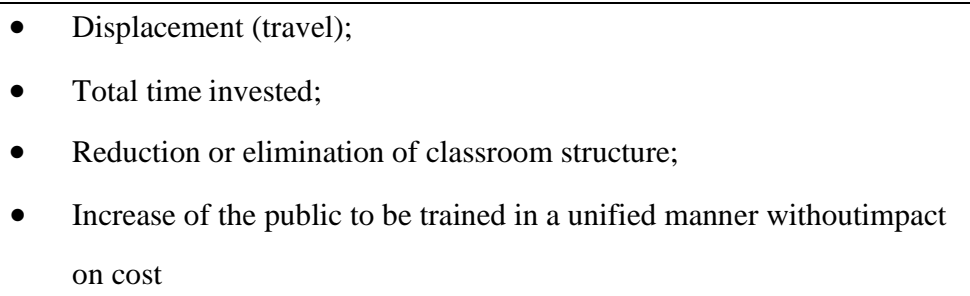 \\
\hline Flexibility of time and place & $\begin{array}{l}\text { - } \text { Planning according to time and space } \\
\text { - } \quad \text { Greater simultaneous reach }\end{array}$ \\
\hline Opening & $\begin{array}{l}\text { - It enables the creation, diversification, and expansion of course } \\
\text { offerings. }\end{array}$ \\
\hline Standardization of teaching & $\begin{array}{l}\text { - Distance learning allows the same course to be applied in differentunits } \\
\text { of the company with identical methodology and content, allowing the } \\
\text { same language and terms to be used. }\end{array}$ \\
\hline
\end{tabular}

Source: Adapted from Carvalho and Freitas (2013).

To evaluate the costs and benefits of both methods, considering the benefits cited by Carvalho and Freitas (2013), an analysis of investments made within the period studied was performed, as described in Figure 10. 
Figure 10 - Investment in training.

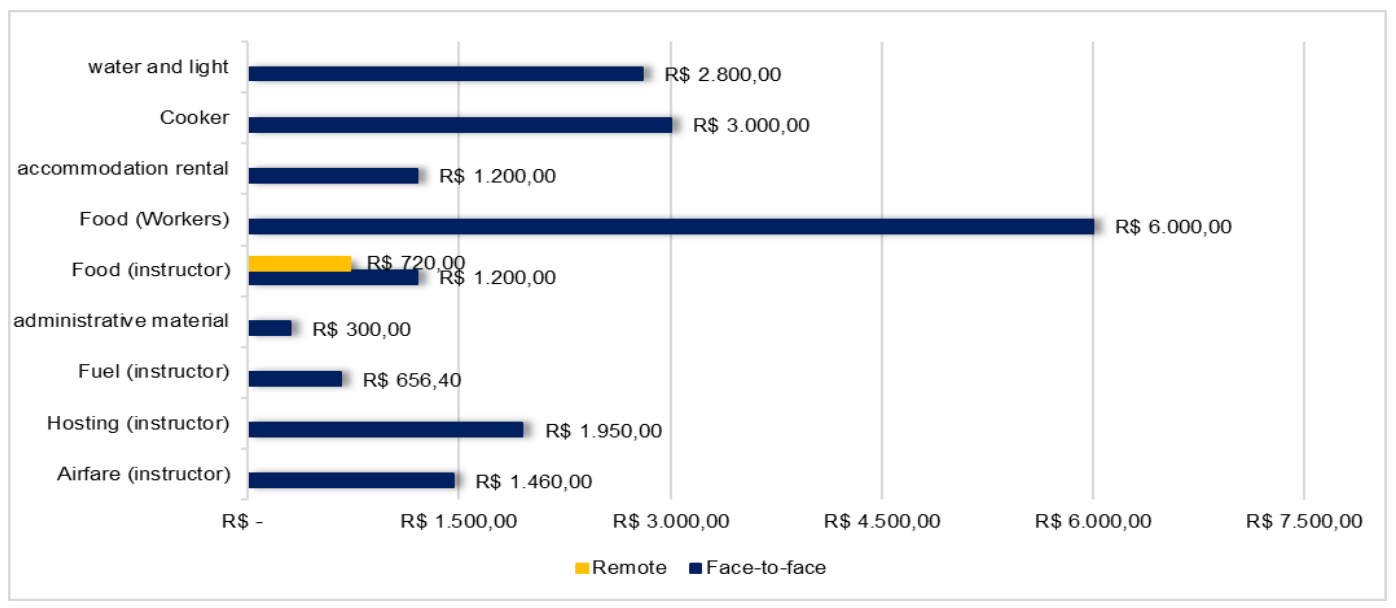

Source: Authors.

The values presented represent the amount invested by the company in the face-to-face training of workers during 2 months, who were in different cities and it became necessary to gather them all in a single location. The total investment in face-to-face training in 2 months was $\mathrm{R} \$ 18,566.40,32 \%$ of which was invested in feeding the workers, since the activity is pulverized, and in order to carry out the face-to-face training, it was necessary to let the workers stay with breakfast, lunch, and dinner. In the remote training, the cost is limited to the meal voucher paid to the instructor, carrying out the training from the company's base. The cost of the in-person training was 26 times that of the remote training. Evaluating the benefit brought by the practical training, we observed that the scores are similar, not affecting the worker's perception of risk, thus, the remote training is of less investment and brought an equivalent performance to the in-person one, having a better cost $\mathrm{x}$ benefit, corroborating Carvalho and Freitas (2013).

The legislation requires that some training must be in person, as for example the integration foreseen in NR-18, however, considering the activity of electrical network construction, according to information from this work, no justification was identified for the in-person requirement, and in this case, being carried out remotely could compromise the worker's learning.

\section{Final Considerations}

Training is essential for the safe development of the activity since knowledge reduces the probability of an unsafe act. However, the pandemic has caused a series of challenges in the realization of training, in which the federal government has relaxed some regulations regarding training in occupational health and safety. Thus, virtual training reduces the chances of workers being contaminated by the disease from COVID-19 within the training environment

Thus, we conclude that training is an important method to reduce accidental events, and as observed in this work, this training can be remote or face-to-face, considering that both training methods had scores above the minimum score to be considered apt (6 points), being effective the remote method, which allows a training with lower investment, reaching people from different locations. The investment in remote training was 26 times lower than the practical training.

Therefore, for the worker profile studied, the transition to the remote method of safety training did not change or alter the way the worker acts safely in the process of electrical network construction. The worker who was trained with the remote method obtained higher average points in theoretical and practical evaluations, when compared with the workers trained in 
Research, Society and Development, v. 11, n. 3, e6011326398, 2022

(CC BY 4.0) | ISSN 2525-3409 | DOI: http://dx.doi.org/10.33448/rsd-v11i3.26398

person, being similar when considering the standard deviation.

The study was limited to professionals who work with electrical network construction, and a suggestion for future studies is to expand it to other sectors and to evaluate in a longer time interval the participants' perception of risk.

\section{References}

ACGIH. (2020). Tailgate Meetings That Work! A Guide to Effective Construction Safety Training, National Ed. American Conference of Governmental Industrial Hygienists. https://www.acgih.org/f.

Almeida Filho, R. R. de ., \& Cruz, F. M. da . (2022). Organizational factors: a case study of the cost-benefit of implementing control measures in precast structure constructions. Research, Society and Development, 11(1), e33711124981. https://doi.org/10.33448/rsd-v11i1.24981

ANEEL - Agência Nacional de Energia Elétrica: Segurança do Trabalho e das Instalações (2022). https://www.aneel.gov.br/seguranca-do-trabalho-e-dasinstalacoes.

Aragão, NA; Pereira-Guizzo, C.; Figueiredo, P (2020). contribuição do e-learning na redução de acidentes de trabalho na indústria. Simpósio Internacional de Educação à distância. Universidade Federal de São Carlos. Anais [...].www.sied-enped2016.ead.ufscar.br/ojs/index.php/2016/article/view/1049/483

ABRACOPEL - Associação Brasileira de Conscientização Dos Perigos De Eletricidade (2021). Anuário estatístico de acidentes. https://abracopel.org/estatisticas/

Barkokébas, B. et al (2020). Segurança e saúde do trabalho para uma cultura prevencionista no ambiente laboral. Editora da Univerisdade de Pernambuco (EDUPE).

Barros, L. C. M. de ., Portella, M. B. ., Brito, D. M. da S. ., Gorayeb , A. L. dos S. ., \& Andrade, M. C. de . (2022). Teachers' perception of remote teaching in medicine during the pandemic by COVID-19. Research, Society and Development, 11(1), e52411125205. https://doi.org/10.33448/rsd-v11i1.25205

Brazil (2021). Secretaria do Trabalho. Normas Regulamentadoras. https://www.gov.br/trabalho/pt-br.

Caetano et al (2015). Desempenho no Enade em ciências contábeis: ensino a distância (EAD) versus presencial. Revista Universo Contábil, 11 (4), 147-165.

Carvalho, D. B \& Freitas, M. C. D. (2013). Capacitação a distância em Saúde e Segurança do Trabalho: Fatores críticos identificados em Curitiba e Região Metropolitana. Semana de la Ingeniería de Producción Sudamericana. Anais XIII SEPROSUL.

Cruz, F. M (2018). Avaliação dos efeitos sinérgicos sobre os trabalhadores expostos a fotores de risco físico em simultâneo. Tese (Doutorado) - Universidade do Minho. Minho.

Costa, P. T. B. (2014) Civil Liability Resulting from Workplace Accident. Monograph (Specialization in Civil Law and Civil Procedure). Centro de Pósgraduação, Pesquisa e Extensão das Faculdades Integradas "Antônio Eufrásio De Toledo". Presidente Prudente, SP.

Dalmau, M., Rodrigues, R., Valente, A. M., \& Barcia, R. (2004) A educação profissional, a EAD e as Universidades Corporativas: Um mercado emergente. Revista Brasileira de aprendizagem aberta e a distância. http://seer.abed.net.br/index.php/RBAAD

Dancey, C. \& Reidy, J. (2005). Estatística Sem Matemática para Psicologia: Usando SPSS para Windows (7 ed.). Penso.

Assis et al. (2011). Study of an online course viability as a training tool in safety of construction sites. In: AREZES P. et al. (eds) International Symposium on Occupational safety and hygiene. occupational safety and hygiene - SHO 2011. Portuguese Society of Occupational Safety and Gygiene (SPOSHO). 100-104.

Enel Distribuições (2022). Critérios de Projetos de Redes de Distribuição Aéreas de Média e Baixa Tensão. https://www.eneldistribuicao.com.br/documentos/ CNS-OMBR-MAT-19-0285-EDBR\%20-20Crit\%C3\%A9rio\%20de\%20Projeto\%20de\%20Redes\%20A\%C3\%A9reas\%20MT\%20BT.pdf.

Filho, D. B. F.; Silva Junior, J. A (2009). Desvendando os Mistérios do Coeficiente de Correlação de Pearson (r). Revista Política Hoje, 18 (1).

Firmino, N. C. S. ., Firmino, D. F. ., Barbano, E. P. ., Mendonça, G. L. F. ., \& Leite, L. R. . (2022). Emergency remote education: actions and adaptations of students from Ceará. Research, Society and Development, 11(1), e18011125028. https://doi.org/10.33448/rsd-v11i1.25028

Google (2021). Google Meet. https://meet.google.com

Google Classroom (2020). Google sala de aula. https://classroom.google.com/.

ILO - International Labor Organization (2020). C081 - Inspeção do Trabalho na Indústria e no Comércio https://www.ilo.org/brasilia/convencoes/WCMS_235131/lang--pt/index.htm.

Mekkodathil, A.; El-Menyar, A.; Al-Thani, H. (2016). Occupational injuries in workers from different ethnicities. Int. J. Crit. Illness Injury Sci. 6 (1), 25-32.

Ministério da Educação (2020). Portaria $N^{o}$ 343, de 17 de Março De 2020. https://www.in.gov.br.

MPT - Ministério Público Do Trabalho (2019). Brasil é quarto lugar no ranking mundial de acidentes de trabalho. https://mpt.mp.br/.

MPT - Ministério Público Do Trabalho (2020). Observatório de Segurança e Saúde no Trabalho. https://smartlabbr.org/sst. 
Research, Society and Development, v. 11, n. 3, e6011326398, 2022

(CC BY 4.0) | ISSN 2525-3409 | DOI: http://dx.doi.org/10.33448/rsd-v11i3.26398

MTE - Ministério do Trabalho e Emprego (2018). Nota técnica 54/2018/CGNOR/DSST/SIT. Brasília, DF.

Netto, A. V (2015). Tecnologia de Treinamento Interativo para Diminuição de Custos e Aumento de Desempenho de Profissionais da Àrea de Segurança Privada e Pública. $A B S E G, 2$ (1).

Oliveira, L. S; Moura, G. R; Kaltmaier Junior, G; Catai, R. E (2017). Reduction of work accidents through security management in a company in the south of Brazil. Revista Espacios. 38 (29), 24.

Rocha, D. S (2020); Readequação do contexto escolar para o formato remoto em meio à pandemia de covid-19: um relato de experiência na ETE Professor Francisco Jonas Feitosa Costa. Pedagogia em Ação. 13 (1)

Santiago, S. B., Pereira, J. G. N. ., Araújo, G. L. de ., Monteiro, M. R. ., \& Sousa, I. F. de . (2022). Learning assessment practices in remote education: an analysis of Chemistry teachers in the Metropolitan Region of Fortaleza - CE. Research, Society and Development, 11(1), e59311125416. https://doi.org/10.33448/rsd-v11i1.25416

Santos Junior, V. B. \& Monteiro, J. C. S (2020). Educação E Covid-19: As Tecnologias Digitais Mediando A Aprendizagem Em Tempos De Pandemia. Revista Encantar - Educação, Cultura e Sociedade, (2) 1, 1-15.

Silva, L. G. G \& Moreira, J.M.L (2019). Possible causes of fatal electrical accidents at work in Brazil. National Meeting of Production Engineering. Encontro Nacional de Engenharia de Produção. Anais [...]. http://www.abepro.org.br/publicacoes/

Silva, G. G. S. (2017). Subnotificação de Acidente de Trabalho Fatal: um estudo de caso no município de Uberlândia. Dissertation (master's degree) Universidade Federal de Uberlândia, Postgraduate Program in Environmental Health and Worker's Health.

Silva, D. G (2018). Diagnóstico de acidentes de trabalho em altura: Um estudo no setor da construção civil. Trabalho de conclusão de curso (Graduação em Engenharia Civil). Universidade Federal do Parnaíba.

Silveira et al (2011). Processo de aprendizagem e inclusão digital na terceira idade. Tecnologia e Sociedade, 7 (13). DOI: 10.3895/rts.v7n13.2581

Skiba, R.; Lehder, G (2005). Taschenbuch Arbeitssicherheit. Erich Schmidt Verlag GmbH \& Co. Vollständig neu bearbeitete.

Sousa et al (2022). Technological strategies used in teaching during the pandemic. Research, Society and Development, 11(1), e20911124762. https://doi.org/10.33448/rsd-v11i1.24762

Tachizawa, T., \& De Andrade, R. O. B (2003). Tecnologias da informação aplicadas às instituições de ensino e às universidades corporativas. Atlas. 